\title{
PENGAMBILALIHAN WEWENANG WALI NASAB DALAM PERKARA WALI ADHAL PERSPEKTIF PLURALISME HUKUM (Studi Kasus Pandangan Hakim dan Tokoh Masyarakat Kabupaten Pasuruan)
}

\author{
A. Fakhruddin ${ }^{*}$ \&uhamad Hasan Sebyar** \\ Pascasarjana UIN Maulana Malik Ibrahim Malang \\ Email: afakhr83@gmail.com
}

\begin{abstract}
Abstrack
The fragility of a father's or father's family relationship with a daughter is one of the causes of Wali Adhol. According to community leaders, the verdict of wali adhal is confusing, because it ignores the wali nasab in marriage, on the other hand the verdict allows the wali adhal to avoid adultery. The case of wali adhal in Pasuruan Regency in 2016 included cases that often occur almost every month. The differences in views between judges and community leaders in Pasuruan Regency regarding wali adhal need to be analyzed in depth, so that they can be taken into consideration about wali adhal in order to reduce the case of wali adhal in Pasuruan. The study employs empirical juridist approach and qualitative descriptive, data from interviews and documentation analyzed with the theory of legal pluralism. The results of the study explained that the case of a wali adhal is in terms of legal pluralism theory that three dimensions will emerge namely first, if a wali nasab does not exist or dies then the judge with available evidence has the right to take over the power of the wali nasab and transfer it to the authorities. Second, if the marriage guardian still has a marriage it must be carried out with the consent of the wali nasab. When the guardian nasab reluctant or absent then the intention to get married should be canceled. Third, if the wali adhol still exists, but due to unjustified reasons the law is reluctant to marry his child, then the judge can allow the wali adhol to avoid adultery and bring justice to girls who have been ostracized.
\end{abstract}

Keywords: Marriage, Wali Adhal, Legal Pluralism

\begin{abstract}
Abstrak
Rapuhnya hubungan ayah atau keluarga ayah dengan anak gadis adalah salah satu sebab wali adhal. Menurut tokoh masyarakat putusan wali adhal itu membingungkan, karena mengabaikan wali nasab dalam pernikahan, di sisi lain putusan hakim mengizinkan wali adhal demi maslahat agar terhindar dari zina. Perkara wali adhol di Kabupaten Pasuruan pada tahun 2016 termasuk perkara yang sering terjadi hampir tiap bulan. Adanya perbedaan pandangan antara hakim dan tokoh masyarakat Kabupaten Pasuruan tentang wali adhal perlu dianalisis secara mendalam, agar dapat menjadi bahan pertimbangan tentang wali adhal guna mengurangi kasus wali adhal di Pasuruan. Jenis penelitian yang digunakan adalah yuridis empiris dan kualitatif deskriptif, data hasil wawancara dan dokumentasi

\footnotetext{
* Dosen Fakultas Syariah dan Hukum Universitas Islam Negeri (UIN) Maulana Malik Ibrahim Malang.

${ }^{* *}$ Dosen Program Studi Hukum Keluarga (Ahwal Syakhshiyah) Sekolah Tinggi Agama Islam Negeri (STAIN) MAndailing Natal.
} 
dianalisis dengan teori pluralisme hukum. Hasil penelitian menjelaskan bahwa perkara wali adhal jika ditinjau dari teori pluralisme hukum akan muncul tiga dimensi yaitu pertama, jika seorang wali nasab tidak ada atau meninggal maka hakim dengan bukti yang ada berhak mengambilalih kekuasaan wali nasab dan memindahkannya kepada pihak yang berwenang. Kedua, jika wali nasab masih ada pernikahan itu harus dilaksanakan dengan persetujuan wali nasab. Ketika wali nasab enggan atau tidak hadir maka niat untuk menikah hendaknya dibatalkan. Ketiga, jika wali adhol masih ada, namun karena alasan yang tidak dibenarkan hukum enggan untuk menikahkan anaknya, maka hakim dapat mengizinkan wali adhal untuk menghindari zina dan mewujudkan keadilan bagi anak perempuan yang telah dikucilkan.

\section{Kata Kunci: Pernikahan, Wali Adhal, Pluralisme Hukum.}

\section{Pendahuluan}

Pengertian wali adhal adalah keengganan wali nasab baik itu dari ayah atau keluarga laki yang sejalur dengan ayah untuk hadir menjadi wali nikah bagi anak perempuannya yang berkeinginan untuk melaksanakan pernikahan. Hal yang mendorong peneliti untuk mendalami perkara wali adhal adalah karena adhal adalah istilah yang dimunculkan oleh para ulama' kontemporer. Oleh karena itu dalam literatur-literatur klasik yang mengulas bab pernikahan tidak pernah ditemukan pembahasan tentang wali adhal, seandainya bisa ditemukan permasalahan yang mirip dengan wali adhal maka itu termasuk dalam pembahasan pernikahan dengan tanpa wali. Berangkat dari putusan pengadilan agama tentang perkara wali adhal, peneliti memulai analisis tentang bagaimana kebijakan putusan wali adhal itu diterbitkan oleh hakim pengadilan agama sehingga hal tersebut menjadi pintu masuk peneliti untuk lebih memperdalam sisi normatif empiris dan sosiologis terjadinya perkara wali adhal di Kabupaten Pasuruan ditinjau dengan teori pluralisme hukum Lawrence M Friedman ${ }^{1}$. Hukum tidak selalu berbanding lurus dengan fenomena sosial. Hal tersebut dapat dilihat dari putusan wali adhal. Setelah adanya penggalian data dengan interview ternyata ada perbedaan argumentasi antara hakim dan tokoh masyarakat. Hakim berargumen bahwa putusan wali adhal itu berdasarkan pada kemaslahatan calon kedua mempelai pengantin agar segera terhindar dari maksiat berbuat zina, hal tersebut sesuai dengan pernyataan salah satu hakim. Pernyataan hakim tersebut bertolak belakang dengan tokoh masyarakat yang tidak berperan langsung dengan pernyataan bahwa keputusan hakim itu tidak sesuai dengan kondisi masyarakat sehari-hari dan membingungkan.

Untuk mempersingkat perbedaan pendapat diantara hukum yang berlaku di dalam sebuah lembaga negara dan hukum yang berlaku setiap hari di dalam sebuah kehidupan bermasyarakat maka putusan hakim menjadi salah satu hal yang diharapkan kehadirannya agar polemik segera diselesaikan dalam tempo yang tidak memakan waktu lama, sehingga kepentingan calon kedua

${ }^{1}$ Lawrence M Friedman, Sistem Hukum Perspektif Ilmu Sosial, (Bandung: Nusamedia, 2017), 282. 
mempelai pengantin untuk melaksanakan pernikahannya segera terlaksana. Kalau wali nasab tetap berpegangan kuat bahwa pernikahan harus dengan persetujuannya maka menjadi hal yang mungkin terjadi adalah pernikahan yang dilandasi atas dasar niat yang tulus akan batal, ada kemungkinan juga keduanya akan tetap menjalin hubungan secara rahasia tanpa sepengetahuan wali nasab. Perkara wali adhol di Kabupaten Pasuruan pada tahun 2016 termasuk perkara yang sering terjadi hampir tiap bulan. Untuk memahami perkara wali adhal dari dua segi yang berlawanan antara fiqih syafi'iyyah dengan KHI peneliti menggunakan teori pluralisme hukum Lawrence M Friedman. Teori pluralisme hukum adalah teori yang fokus membahas tentang aneka ragam hukum yang berlaku di masyarakat; baik itu formil maupun non formil. Jika kedua hukum tersebut berjalan secara berdampingan maka bisa dipastikan akan terjadi gesekan kepentingan diantara keduanya. Kalau dikaitkan dengan perkara wali adhal; hukum yang berlaku di masyarakat mewajibkan pernikahan dengan persetujuan wali nasab, hal itu bertolak belakang dengan hukum yang berlaku di pengadilan yang menyediakan peluang calon pengantin untuk tidak menganggap kerelaan wali nasab sebagai hal yang penting dalam sebuah pernikahan.

Al-Saqaf berpendapat bahwa wali termasuk dari satu dari lima unsur yang harus ada dalam pernikahan yang kemudian unsur tersebut dinamakan dengan rukun. Adapun rukun dalam pernikahan ada lima, Pertama, Adanya seorang wali pria dari pihak ayah, Kedua, Ada dua orang saksi pria, Ketiga, Ada dua orang mempelai calon pengantin pria dan wanita, Keempat, Adanya ijab, Kelima, Adanya qabul. ${ }^{2}$ Para ulama' Malikiyyah, Syafi'iyyah, dan Hanabilah sependapat bahwa wali adalah termasuk unsur yang menentukan keabsahan pernikahan. Sedangkan Hanafiyyah berbeda pendapat dengan para ulama' dalam hal adanya seorang wali itu diwajibkan ketika calon mempelai wanita masih belum dewasa atau sudah dewasa akan tetapi memiliki kekurangan cacat mental. Hanafiyyah berpendapat bahwa anak yang berakal dan sudah baligh baik itu gadis atau janda berhak untuk menikahkan diri mereka sendiri dengan syarat kedua mempelai sederajat atau kafa'ah, karena jika tidak sederajat maka wali berhak membatalkan perkawinannya. ${ }^{3}$ Ditegaskan dalam pasal 23 Kompilasi Hukum Islam bahwa seorang wali hakim boleh berlaku seperti wali nasab jika wali nasab tidak ada atau tidak mungkin dihadirkan atau tidak diketahui rumahnya atau ghaib atau adhal atau enggan. Ketika wali nasab tidak berkenan untuk menjadi wali nikah maka wali hakim berhak menggantikan posisi wali nasab untuk menikahkan seorang wanita, hal itu bisa terjadi jika sudah ada putusan pengadilan agama bahwa wali telah adhal. Nahdlatul Ulama' sebagai organisasi keagamaan terbesar di Indonesia yang dianut oleh mayoritas muslim

${ }^{2}$ Alwi al-Saqqaf, Fath al-Mu'in ( Beirut:Dar al-Fikr,tt ), 300.

${ }^{3}$ Abdul Rahman al-Jazairi, al-Figh Ala Madzahib Al-Arba'ah,( Beirut: Dar al-Fikr,tt), 300. 
termasuk di Kabupaten Pasuruan melalui PBNU telah menelurkan fatwa yang berlawanan dengan apa yang tertulis dalam KHI tentang perkawinan tanpa persetujuan wali nasab. ${ }^{4}$ Berdasarkan ulasan sederhana tersebut maka perkawinan yang dilaksanakan tanpa ada persetujuan dari wali nasab dari pihak wanita itu dihukumi tidak sah karena mengabaikan wali yang menjadi salah satu rukun dalam pernikahan. Permasalahan tersebut menjadi berbeda ketika seorang wali nasab mewakilkan kepada orang lain yang memenuhi ketentuan perwalian.

Perkawinan menurut istilah seperti dikemukakan Muhammad Abu Zuhroh adalah akad yang bisa menjadikan halalnya hubungan badan antara seorang pria dan wanita, disertai dengan unsur adanya saling tolong menolong diantara keduanya sehingga menimbulkan hak dan kewajiban dalam berumah tangga sesuai dengan peraturan yang berlaku dalam islam. ${ }^{5}$ Adapun tujuan pernikahan dalam islam itu sebagaimana tertulis dalam QS. al-Rum 21 adalah agar merasa tentreram dan terjalin kasih sayang.

Al-Qurthubiy menjelaskan dalam ayat tersebut Allah menjelaskan tiga poin yang berkaitan dengan rumah tangga ideal dalam islam. Poin tersebut adalah sakinah, mawaddah, dan rahmah. Bermula dari kehidupan berumah tangga yang sakinah (tentram) dan mawaddah (penuh kasih sayang) itu nantinya diharapkan akan mendapatkan rahmah keturunan yang sehat dan penuh berkah dari Allah SWT, sekaligus sebagai pencurahan rasa cinta dan kasih suami kepada isteri dan anak-anak. ${ }^{6}$

Fuqaha' mengungkapkan beberapa tujuan dan inti dari sebuah pernikahan yang bisa diambil dari QS. al-Rum 21 tersebut adalah dengan adanya syari'at perkawinan kita dapat mengambil banyak hikmah dan manfaat. Adapun manfaat dan hikmah dari sebuah pernikahan seperti disampakan al-Jurjani adalah sebagai berikut: ${ }^{7}$ Pertama, Melestarikan keturunan umat Nabi Muhammad SAW, hal tersebut sesuai dengan hadits yang maknanya adalah menikahlah dan milikilah beberapa anak, karena sesungguhnya aku akan bangga denganmu nanti di hari kiamat, Kedua, Mendidik manusia agar memiliki rasa cinta, kasih sayang, jiwa yang lembut terhadap sesama manusia, dan kesamaan rasa diantara kedua pasang insan manusia, karena keduanya tercipta berbeda agar saling melengkapi.

Manfaat perkawinan seperti yang diungkapkan para ulama' fiqih diatas bermakna sama dengan undang-undang perkawinan tahun 1974 pasal 1 bab 1 yang menyatakan bahwa: "Perkawinan adalah ikatan lahir dan batin antara seorang pria dengan seorang wanita sebagai suami isteri dengan tujuan

${ }^{4}$ http://www.nu.or.id/post/read/73239/nikah-tanpa-restu-orang-tua-perempuan, diakses tanggal 3 Oktober 2018

${ }^{5}$ Abu Zahroh, Figh Al-Islam, (Cairo: Dar al-Manar,1990), 334.

${ }^{6} \mathrm{Abu}$ Abdillah al-Qurthuby, al-Jami' li Ahkami al-Qur'an, (Beirut: Dar al-Fikr, tt), Juz $\mathrm{XIV}, 16$.

7Ali Ahmad al-Jurjani, Hikmah al-Tasyri' wa Falsafatuhu, (Beirut: Dar al-Fikri,1974), 102. 
membentuk keluarga yang bahagia dan kekal berdasarkan ketuhanan yang maha esa. Selaras dengan undang-undang diatas KHI pasal 2 juga menyebutkan bahwa pernikahan adalah:"Akad yang sangat kuat atau mitsaqan ghalidzan untuk mentaati perintah Allah SWT dan melaksanakannya adalah ibadah." 8

Perkawinan yang dilaksanakan di Indonesia harus sesuai dengan peraturan yang berlaku, seperti halnya PP No.9 Tahun 1975 jo dan PERMENAG No.3 Tahun 1975 tentang pencatatan nikah, talak, dan rujuk ( UU No.1 Tahun 1974 ). Menurut KHI pasal 28 disebutkan bahwa akad nikah itu boleh dilakukan sendiri oleh wali nikah yang bersangkutan atau wali nikah mewakilkan kepada pegawai pencatat nikah atau orang lain yang dianggap memenuhi syarat. ${ }^{9}$ Dalam UU No.1 Tahun 1974 tidak disebutkan dengan jelas peraturan tentang adanya wali nikah, akan tetapi hanya mensyaratkan harus diberi izin oleh orang tua apabila calon pengantin belum genap berumur 21 tahun, meskipun demikian UU ini telah menjadi dasar dalam pernikahan di Indonesia, terkhusus bagi umat muslim, hal tersebut sesuai dengan makna dari pasal 4 ayat 1 yang menyatakan bahwa perkawinan adalah sah apabila dilakukan menurut hukum islam sesuai dengan undang-undang perkawinan.

Pernyataan Lawrence M Friedman tentang memprioritaskan hukum positif ketika terjadi gesekan antara hukum islam dan positif bisa jadi landasan berpikir bagi hakim ketika menemui konflik diantara dua hukum yang saling berebut untuk menempati posisi. Friedman juga menyatakan karakter lain dari kultur hukum modern adalah unifikasi hukum. Pada kesempatan ini penulis memaparkan dua hukum yang saling berebut untuk mengikat, bahkan seringkali bertentangan antara hukum adat dan pemerintah. Ketika keduanya saling berebut maka yang dianggap adalah pemerintah, karena hukum pemerintah disamping tertulis juga berlaku untuk semua kalangan masyarakat; diskresi hukum akan menafikan hukum yang plural, minimal dalam cakupan informal, dan di masa modern hukum akan tampak seperti tidak adil, meskipun demikian bangsa yang modern membutuhkan unifikasi tunggal hukum nasional. ${ }^{10}$ Salah satu solusi dari sebuah konflik adalah dengan mengorbankan pihak lain sembari berusaha untuk mencapai titik kompromi dari permasalahan yang saling berlawanan. Adanya ungkapan bahwa hanya satu yang adil dari dua tatanan hukum itu tidak bisa dibuktikan secara ilmiah. Tatanan hukum positif berusaha menghadirkan hukum yang riil dan mungkin terjadi, bukan hukum yang benar, dan suatu teori yang benar-benar realistis dan empiris adalah tatanan hukum

${ }^{8}$ Arso Sastroatmodjo dan Wasit Aulawi, Hukum Pernikahan di Indonesia, (Jakarta: Bulan Bintang, 1975), cet 1, 80.

${ }^{9}$ Idris Ramulyo, Hukum Perkawinan, Kewarisan dan Hukum Acara Pengadilan Agama dan Zakat, (Jakarta: Sinar Grafika, 2006), hlm 36.

${ }^{10}$ Lawrence M Friedman, Sistem Hukum Perspektif ..., 282. 
positif. ${ }^{11}$ Berawal dari konteks penelitian diatas, maka rumusan masalah yang menjadi fokus pembahasan pada penelitian ini adalah menggambarkan bagaimana Pertimbangan hakim pengadilan agama dan tokoh masyarakat tentang pengambilalihan wewenang wali nasab oleh hakim dalam perkara wali adhal dan penjelasan tentang penerapan teori pluralisme hukum terhadap permasalahan.

\section{Metode Penelitian}

Jenis penelitian ini tergolong penelitian lapangan, yang memiliki arti bahwa penelitian ini mengharuskan peneliti untuk langsung turun ke lapangan guna mempelajari secara intensif untuk mendapatkan data yang lengkap dan berimbang. tujuan dari penelitian ini adalah untuk mengamati secara intensif tentang kondisi dan situasi sekarang, baik dari segi individu, sosial, maupun lembaga. Penelitian ini terkonsentrasi pada kebijakan dalam mengeluarkan putusan wali adhal disertai dengan analisis sesuai dengan teori pluralisme hukum dan selanjutnya diiringi dengan opini hakim pengadilan agama dan tokoh masyarakat Kabupaten Pasuruan terhadap perkara pengambilalihan wewenang wali nasab dalam perkara wali adhal. Penelitian ini menggunakan metode penelitian kualitatif yang berdasarkan filsafat postpositivisme. Metode ini digunakan untuk meneliti obyek alami pada penelitian ini, dan yang menjadi instrumen kunci adalah peneliti sendiri. Sedangkan cara mengumpulkan data dengan meetode triangulasi, untuk analisisnya bersifat kualitatif, sedangkan hasil penelitiannya lebih fokus pada makna. ${ }^{12}$ Penelitian ini berjenis penelitian normatif empiris dengan menggunakan data primer yang berasal dari wawancara di lapangan kepada para narasumber yang mengetahui, mengamati fenomena di lapangan. Sebagai pendukung peneliti memakai pendekatan soiologis. Teori yang dipakai dalam penelitian ini adalah pluralisme hukum Lawrence M Friedman, teori tersebut membutuhkan sebuah tatanan yang nyata, bukan hanya yang tertulis. ${ }^{13}$

Dalam penelitian ini ada dua sumber data yang menjadi sarana untuk mempermudah analisis permasalahan: Pertama. Sumber Data Primer, Kedua. Sumber Data Sekunder. Sumber data primer adalah data yang dikumpulkan dan didapatkan dari sumber utama data yaitu wawancra untuk mengetahui pandangan hakim pengadilan agama dan tokoh masyarakat dari berbagai kalangan yang mengetahui permasalahan, baik itu yang berperan langsung terhadap perkara maupun yang tidak berperan langsung. Sedangkan sumber data sekunder ialah data yang terkumpul dari beberapa dokumen baik itu

\footnotetext{
${ }^{11}$ Hans Kelsen, Teori Hukum Murni, Dasar-Dasar Ilmu Hukum Normatif (Bandung: Nusamedia,2016), hlm 16

${ }^{12}$ Sugiyono, Metodologi Penelitian Kualitatif dan Kuantitatif, ( Bandung: Alfabeta, 2008), 9.

${ }^{13}$ Lawrence M Friedman, Sistem Hukum Perspektif Ilmu Sosial, ( Bandung: Nusamedia, 2017 ), 283.
} 
berupa putusan hakim pengadilan agama Kabupaten Pasuruan maupun dokumentasi, bahan literatur lain yang berfungsi sebagai pendukung dari teori utama pluralisme hukum Lawrence M Friedman. Secara umum perincian wawancara dalam penelitian ini adalah sebagai berikut: Pertama, Wawancara dilakukan dengan semi-terstruktur, dengan mempersiapkan bahan pertanyaan wawancara. Dalam perjalanannya pertanyaan akan sedikit berkembang dari pedoman, hal itu dilakukan agar narasumber bebas beropini. Kedua, Wawancara dilakukan mendalam, terstruktur melalui wawancara yang terukur, mendalam agar data sesuai sasaran.

\section{Pengambilalihan Wewenang Perwalian Pada Perkara Wali Adhol Perspektif Hakim Dan Tokoh Masyarakat}

Semua lembaga peradilan, tak terkecuali lembaga peradilan agama memiliki jiwa keadilan untuk semua golongan lapisan masyarakat, tidak hanya disitu produk hukum yang dihasilkannya juga harus memiliki manfaat yang nyata karena jika tidak ada keadilan dari putusan yang dikeluarkan lembaga peradilan maka manusia akan terus mengikuti tabiat nafsu yang selalu mengajak untuk melakukan perbuatan yang menyalahi sunnatullah dengan saling berebut untuk mendapatkan hak, jika hukum tidak memberikan manfaat yang nyata berupa kedamaian hidup bermasyarakat, maka hukum tidak akan dianggap masyarakat berwibawa. karena kewibawaan sebuah hukum itu sering dilihat bukan dilihat dari ketegasan sebuah keputusan, akan tetapi manfaat dari sebuah putusan itu untuk kedamaian masyarakat.

Adil dan manfaat seringkali saling bertolak belakang dalam kejadian nyata, jika mengedepankan keadilan maka sudah dapat dipastikan manfaat berupa kedamaian hidup yang akan dikorbankan untuk harus mengalah, begitupun sebaliknya jika menjadikan keadilan sebagai sebuah prioritas maka akan merobohkan tatanan sosial kedamaian hidup yang telah terbangun jauh sebelum keadilan itu dimunculkan. Oleh karena itu disamping memiliki jiwa keadilan sebuah putusan hakim yang tertulis selayaknya juga harus memiliki ruh kebermanfaatan hukum yang seringkali tak tertulis, demi terjadinya hukum yang berkeadilan dan mensejahterakan kehidupan, agar harmonisasi hidup bermasyarakat tetap berlangsung, hal itu juga berlaku dalam perkara wali adhal.

Pada perkara wali adhal jika seorang hakim dengan wibawa yang dimilikinya hanya melihat keadilan dari pemohon semata maka bangunan kesejahteraan dan keharmonisan hidup dari adanya kebiasaan menghormati wali dengan membatalkan keinginan untuk menikah jika tidak disetujui wali nasab yang sudah terjaga menjadi runtuh. Begitupun sebaliknya jika berpegangan pada bangunan kesejahteraan hidup maka kepentingan mendesak seorang anak untuk segera menikah akan terabaikan. Oleh karena itu hakim dengan kebijakan putusannya yang berkeadilan hendaknya juga melihat kondisi masyarakat secara berimbang sebagai bahan rekomendasi putusan. 


\section{Fenomena Hukum Darurat Perkara Wali Adhal}

Adapun bentuk darurat menurut Imam Haramain seperti dijelaskan alSyathibiy ada tiga ${ }^{14}$ :

1) Dlaruriyyat

Dlaruriyyat adalah ketika keadaan memaksa seseorang harus menjaga lima hal pokok, Adapun kelima hal pokok yang harus dijaga menurut al-Syathibi itu adalah agama, nyawa, akal, nasab, harta. Ketika lima hal dasar tersebut diabaikan maka bahaya besar akan mengancam dengan nyata.

\section{2) Hajiyyat}

Hajiyat adalah ketika tidak dilakukan suatu perkara, maka keadaan akan menjadi bertambah buruk, akan tetapi tidak sampai kepada kerusakan dan kehilangan sesuatu.

\section{3) Tahsiniyyat}

Tahsiniyat adalah ketika tidak dilakukan suatu perkara, maka keadaan akan tidak akan menjadi bertambah buruk, dan jauh untuk sampai pada kerusakan.

Pada perkara wali adhal permasalahan yang ada didalamnya tergolong dlaruriyyat, karena jika tidak segera diputuskan anak berhak menikah, maka kekhawatiran akan rusaknya unsur penjagaan terhadap kesucian nasab hifdzu alnasl akan nyata terjadi. Perkara wali adhal dianggap hakim sebagai dlaruriyyat, karena jika hakim tidak memutuskan bahwa anak berhak menikah meskipun orang tuanya tidak setuju maka kemungkinan terdekat yang akan terjadi adalah terjadinya zina yang berujung pada kehamilan diluar pernikahan yang sah. Perkara wali adhal yang tergolong darurat itu bisa kita gambarkan sebagaimana halnya ketika terjadi sengketa antara wali nasab dan anak sebagai calon pengantin perempuan menginginkan menikah dengan calon pilihannya sendiri, akan tetapi tidak ditemukan satu kata kesepakatan; wali tidak mau datang untuk menjadi wali nasab dalam pernikahan. Jika mengikuti keinginan wali nasab untuk melestarikan hukum, maka hak keadilan calon pengantin untuk melaksanakan syari'at islam akan terhalang, begitupun sebaliknya; jika putusan wali adhal dilaksanakan, maka sendi kehidupan bermasyarakat akan roboh, hal itu disebabkan karena lunturnya sebuah tradisi yang sudah berjalan. permasalahan memohon izin kepada wali nasab untuk menikah, telah berlaku secara umum di masyarakat jika seseorang hendak menikah diwajibkan untuk meminta persetujuan wali nasab agar barokah do'a pernikahan bisa didapat.

${ }^{14}$ Al-Syathibi, Al-Muwafaqot, ( Beirut: Dar al-Fikri, 2010 ), 58. 
ketika barokah do'a didapat maka kemudahan dalam menjalani kehidupan rumah tangga akan tercapai.

Perkara wali adhal secara terperinci tidak diatur dalam undang-undang perkawinan tahun 1974, akan tetapi perkara wali adhal tersebut bisa ditemukan di dalam Kompilasi Hukum Islam yang didalam pasal 23 dinyatakan bahwa Wali hakim baru dapat bertindak sebagai wai nikah apabila wali nasab tidak ada atau tidak mungkin menghadirkannya atau tidak diketahui tempat tinggalnya atau gaib atau adlal atau enggan serta jika wali adhal atau enggan maka wali hakim baru dapat bertindak sebagai wali nikah setelah ada putusan Pengadilan Agama tentang wali tersebut. Adapun wali adhal jika ditinjau dari fenomena yang terjadi di masyarakat ada tiga: pertama, wali dan calon pengantin terpisah oleh jarak yang jauh. Kejadian ini bermula dari disharmonitas hubungan antara wali dengan calon pengantin, hal tersebut terjadi karena kedua orang tua pasangan calon mempelai perempuan telah bercerai, sehingga calon pengantin perempuan memilih untuk tinggal terpisah dari bapak kandung. Hal tersebut berlanjut ketika seorang anak membutuhkan kehadiran bapak sebagai wali nikah. Ketika wali tidak dapat dihadirkan maka hak wali nasab tersebut diambilalih oleh hakim. Hal tersebut seperti yang disebutkan dalam KHI pasal 23 ayat 1 sebagai berikut: Wali hakim baru dapat bertindak sebagai wali nikah apabila wali nasab tidak ada atau tidak mungkin menghadirkannya atau tidak diketahui tempat tinggalnya atau gaib atau adhal atau enggan. Dalam prakteknya ketika wali nasab enggan menjadi wali nikah, maka ketika putusan wali adhal keluar dari pengadilan yang berhak menjadi wali dalam sebuah pernikahan yang akan dilaksanakan oleh seorang calon mempelai pengantin perempuan adalah pejabat KUA. Hal tersebut terjadi karena calon mempelai pengantin perempuan tidak memiliki wali nasab sama sekali, atau bisa juga karena wali adhal; menolak menjadi wali nikah, atau karena jarak yang jauh antara anak dengan wali nasab. Seharusnya jarak antara calon mempelai pengantin perempuan dengan wali nasab tidak dijadikan alasan untuk tidak merestui pernikahan anaknya, karena dalam islam jarak perjalanan tidak bisa membebaskan seseorang dari kewajiban sholat, seberapapun jauhnya perjalanan yang harus ditempuh, apalagi di zaman sekarang yang serba digital. Seharusnya komunikasi tetap berlanjut, terutama ketika anak akan menikah. Kedua, Unsur mistis wali nasab. Sebagian masyarakat masih banyak yang masih mempercayai mitos yang berasal dari luar ajaran islam, seperti halnya klenik, mitos tentang keterkaitan hari sial, hari pasaran, dan fenomena alam dengan nasib seseorang yang dalam hadits disebut dengan tathoyyur yang berarti ramalan. Hal tersebut sesuai dengan hadits Nabi Muhammad SAW:

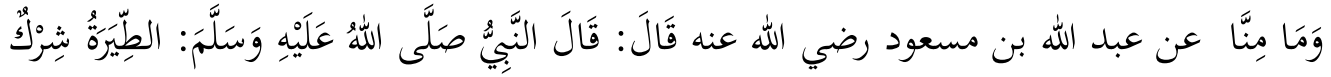

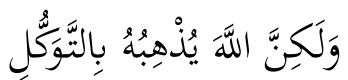


Artinya: Dari Abdullah bin Umar RA berkata: Nabi Muhammad SAW bersabda: Meramal itu syirik, oleh karena itu Allah SWT menyuruh kita tawakkal.

Islam mengharamkan seseorang untuk meramal, karena ramalan itu berarti menebak takdir Allah SWT. dan Allah tidak menyuruh kita untuk meramal, karena ramalan itu sering bersumber dari syetan yang mendapat bocoran informasi tentang nasib seseorang. Allah SWT menyuruh kita untuk berusaha dengan maksimal dan berdo'a agar diberikan yang terbaik dan terhindar dari keburukan disertai dengan tawakkal berserah diri dengan keputusan Allah SWT, bukan untuk meramal yang akan terjadi, ketika usaha itu berhasil maka kita harus banyak bersyukur, Sebaliknya ketika usaha kita gagal diperintah untuk sabar dan mengulang lagi, dan keduanya dihitung Allah SWT sebagai ibadah syukur dengan nikmat keberhasilan dan sabar dengan kegagalan untuk kemudian berusaha lagi.

Kaum modernis muslim beranggapan bahwa dalam syariat semua hari adalah baik, tidak ditemukan pembahasan tentang hari sial dan hari beruntung, mengenai hari kelahiran itu hanya bersumber dari kebiasaan, tidak boleh terlalu dipercaya, yang terpenting adalah berusaha dan tawakkal diiringi dengan sabar. Yang terpenting dalam menjalani kehidupan rumah tangga adalah kedewasaan masing-masing pasangan untuk menghadapi kenyataan hidup dengan sikap yang bijaksana. Kesimpulannya adalah ketika nash yang mengharuskan menikah didampingi oleh wali bertentangan dengan kondisi di lapangan yang mengharuskan pernikahan harus segera dilaksanakan tanpa melalui persetujuan wali nasab, maka demi maslahat yang lebih besar dan mendesak dengan melaksanakan perkawinan meski tanpa disetujui wali nasab itu berhak untuk didahulukan daripada mengamalkan nash yang mewajibkan nikah dengan wali. Ketiga, anak terlanjur akrab sebelum izin menikah. Islam adalah agama yang mengatur dan membatasi pergaulan dengan lawan jenis hal itu dilakukan dalam rangka melindungi diri dari godaan setan. Nabi menjelaskan larangan untuk berdua dengan lawan jenis dengan hadits yang diriwayatkan dari Amir bin Robi'ah berkata: Nabi Muhammad SAW bersabda: Lelaki dan perempuan janganlah berdua, karena setan itu pasti ada di pihak ketiga yang siap menggoda manusia, sungguh tidak ada orang yang ketiga selain mahram itu adalah setan. (HR.Ahmad).

Kedekatan hubungan seperti digambarkan dalam hadits diibaratkan sampai pada terjerumusnya kedua pasangan kepada bujukan dan rayuan setan hingga sampai berani melakukan perbuatan yang menjurus pada hubungan zina yang terlarang. Hal tersebut terjadi karena hubungan kedua jenis manusia yang bermula dari hubungan yang tanpa didasari oleh iman sebagai kontrol diri, Adanya hadits yang melarang sepasang dua insan manusia yang berbeda jenis tersebut jika ditinjau dari salah satu dari lima kaidah fiqih dasar mendahulukan tercegahnya kerusakan lebih diutamakan daripada mengambil manfaat itu bermakna sama sebagai langkah antisipatif untuk menghindari zina dengan 
berdasarkan hadits yang diriwayatkan oleh Ibnu Majah. Adapun hadits tersebut adalah sebagai berikut:

$$
\text { عَنْ ابْنِ عَبَّاسِ قَالَ: قَالَ رَسُولُ اللَّهِ صَلَّى اللهُ عَلَيْهِ وَسَلَّمَ: لَا ضَرَرَ وَلَا ضِرَار }
$$

Artinya: Ibnu Abbas berkata: Rasulullah bersabda: tidak boleh membahayakan diri sendiri dan orang lain.

Pada fakta yang terjadi di lapangan seringkali kedekatan hubungan serius lawan jenis yang tanpa ada batasan itu berujung pada hubungan di luar pernikahan yang hal tersebut berdampak sampai pada terjadinya kehamilan di luar pernikahan yang resmi. Persoalan makin menjadi rumit ketika sampai terjadi kehamilan, wali nasab malah terkadang tidak mau bertanggung jawab menjadi wali nikah dengan alasan malu, karena aib keluarga akan dilihat orang banyak. ketika wali nasab tidak mau menjadi wali nasab maka yang menjadi korban karena malu dipandang negatif mayoritas masyarakat adalah anak perempuan yang akan menjadi pengantin.

Fenomena stigma negatif terjadinya kehamilan diluar nikah yang berasal dari mayoritas masyarakat itu adalah salah satu dari fenomena dari struktur sosial tokoh masyarakat yang membentuk sebuah hukum yang berasal dari fenomena sosial yang terjadi di masyarakat untuk memaksa masuk menjadi hukum agar diputuskan bahwa wali telah abai dengan kondisi calon pengantin perempuan dan wali dianggap adhal.

\section{Pengambilalihan Wewenang Wali Nasab Dalam Perkara Wali Adhal Perspektif Teori Pluralisme Hukum.}

Berlakunya hukum di dalam masyarakat yang plural itu nyaris mustahil diberlakukan ketika sebuah subkultur sekelompok orang berbeda pandangan dengan yang lainnya dalam arti lain tidak adanya kekompakan dalam satu kultur. Hal itu terjadi dikarenakan tiga hal ${ }^{15}$ : Pertama, Hukum bukan satusatunya sumber bagi munculnya imbalan dan hukuman. Kedua, Manusia bukanlah mesin melainkan makhluk yang bermoral yang memiliki ide dan nilai tersendiri, dan bagian ketiga yang terakhir adalah kita tidak bisa berasumsi bahwa subyek hukum sepenuhnya berhenti. Ketika pemegang kekuasaan memberikan perintah kepada lembaga tertentu agar dipatuhi dan dijalankan untuk kemudian disebar luaskan kepada masyarakat maka sejak saat itulah hukum mulai berjalan, dan jika wali berkehendak maka wali berhak menggugat putusan hakim dan membatalkan pernikahan anak. Dalam masyarakat sebuah negara akan kita temukan banyak kultur adat dan norma yang berlaku didalam masyarakat, hal itu karena banyaknya dialektika yang ada didalamnya dengan adanya imbalan dan hukuman atas sebuah perilaku; itu juga dapat tergambar

\footnotetext{
${ }^{15}$ Lawrence M Friedman, Sistem Hukum Perspektif Ilmu Sosial, ( Bandung: Nusamedia, 2017 ), 139.
} 
dalam sebuah kasus wali adhal dimana lembaga peradilan yang memberikan jalan untuk menikah berlawanan dengan norma adat yang yang melarang anak untuk melanjutkan pernikahannya. oleh karenanya hakim bisa memanfaatkan seluruh potensi yang ada di masyarakat termasuk tokoh yang yang dianggap disegani oleh kedua belah pihak; baik itu disegani wali nasab maupun calon pengantin agar konflik segara berakhir.

\section{Pengambilalihan Wewenang Wali Nasab Perspektif Kultur Hukum}

Jika hukum itu ingin diakui masyarakat tanpa adanya unsur pemaksaan maka disamping harus rasional, hukum harus bermula dari kebiasaan masyarakat untuk mematuhi hukum, yang pada puncaknya hukum itu akan menjadi budaya, ketika hukum sudah menjadi budaya untuk kemudian hukum itu diangkat pemerintah sebagai sarana instrumental bagi ketertiban hidup bermasyarakat agar mendapat legitimasi secara luas maka menjadi hal yang tidak sulit untuk mewujudkan hukum yang diakui legitimasinya baik di jalur struktural maupun prosedural, begtu juga ketika hakim memutuskan untuk mengambilalih wewenang wali nasab dalam fenomena pernikahan anak yang menghadapi masalah karena wali adhal.

Ketika hukum yang telah memenuhi syarat legitimasi itu berjalan sesuai dengan harapan sebagaimana mestinya maka sebagai tindak lanjut struktural prosedural hakim melalui putusan pengadilan berhak memerintahkan pejabat yang dalam hal ini KUA yang berwenang agar segera bertindak sebagai wali hakim dari anak yang pernikahannya tidak disetujui oleh wali nasab, hal itu dilakukan demi keadilan bagi seorang anak agar segera terhindar dari maksiat zina.

Keputusan tersebut dikeluarkan karena indonesia adalah negara hukum yang menganut keadilan sosial bagi seluruh rakyat indonesia. Hal itu sesuai dengan apa yang telah disebutkan dalam UUD 1945 dalam pasal 1 ayat 3 bab 1 yang telah diamandemen, disana disebutkan bahwa dasar negara indonesia adalah hukum yang berdasarkan konstitusi sistematis yang berlandaskan hukum yang telah tersusun sedemikian rupa agar terjadi keselarasan dalam masyarakat bukan absolutisme konstitusi yang hukum tersebut diciptakan penguasa demi kepentingan langgengnya kekuasaan, ketika putusan hakim tersebut dilakukan dengan cara-cara yang sistematis, prosedural dan terlegitimasi maka hukum yang harmonis akan tercipta.

Kultur hukum jika dimaknai secara luas maka akan ada keterkaitan hukum dengan fenomena sosial yang terjadi di masyarakat. Fenomena sosial itu bisa berupa pemahaman masyarakat terhadap sebuah hukum yang tersusun secara sistematis. ${ }^{16}$ Pemahaman dasar tentang sebuah peraturan dalam

${ }^{16}$ Lawrence M Friedman, Sistem Hukum Perspektif ..., 151. 
pernikahan itu terwujud dari bersatunya dua jenis manusia yang sesuai dengan ketentuan syari'at islam yang disertai dengan adanya iringan do'a restu masyarakat termasuk didalamnya adalah wali nasab bagi kedua pasangan sebagai bekal untuk mengarungi bahtera rumah tangga.

Ketika wali nasab tidak hadir menjadi wali nikah dan tidak menyetujui pernikahannya maka dapat dipastikan stigma yang akan muncul di masyarakat adalah pandangan negatif, meskipun friedman berpendapat bahwa hukum itu tidak selalu berangkat dari opini masyarakat, ${ }^{17}$ akan tetapi hal tersebut akan terlihat sama dengan pernyataan Friedman bahwa anggapan masyarakat akan berpengaruh terhadap hukum seperti halnya kekuatan hukum dan kekuatan ekonomi dalam fenomena terciptanya sebuah pasar. Kemiripan tersebut dapat digambarkan sebagai berikut: Pertama, ada sebagian orang yang berkepentingan dengan satu komoditas, sampai komoditas itu terasa penting.

Hal itu bisa tergambar dengan narasi ketika sebagian masyarakat dalam hal ini calon pengantin perempuan yang merasa sangat membutuhkan perlindungan hukum ketika berhadapan dengan wali nasab yang telah meningggalkan tanggung jawabnya yang terakhir untuk menikahkan anak perempuannya, di sisi lain terjadi paradoksi hukum juga terjadi dalam masyarakat, ada yang mendukung calon pengantin untuk menikah demi memenuhi kebutuhan dasarnya yang mendesak, sementara di sisi lain sebagian masyarakat seperti dalam bab sebeumnya melarang untuk melanjutkan kehendaknya untuk menikah agar tradisi dalam masyarakat tetap terus terjaga.

Berasaskan keadilan untuk dirinya sampai pada tingakatan jika tidak ada kejelasan hukum akan berakibat terjadinya hubungan yang tidak diinginkan seorang hakim harus bertindak melindungi hak asasi anak perempuan yang telah diamanatkan undang-undang dasar 1945 pasal $28 \mathrm{~b}$ tentang hak untuk membentuk keluarga, seperti dinyatakan dengan pernyataan bahwa setiap orang berhak untuk membentuk keluarga dan melanjutkan keturunan melalui perkawinan yang sah. Kedua, ada sebagian orang yang berkuasa dan kaya daripada yang lainnya.

Pada poin ini dapat kita ambil analogi ketika seorang wali dengan dukungan opini publik dihadapkan dengan seorang anak yang akan melaksankan pernikahan, maka yang ada di benak sebagian masyarakat yang masih memiliki rasa nurani keadilan adalah anak telah ditelantarkan yang seharusnya bertindak sebagai wali nasab, akan tetapi wali tidak memberikan izin untuk menikah dengan berbagai alasan yang telah disampaikan sebelumnya. Pada momen seperti ini wali nasab memiliki kewenangan penuh untuk melepas anaknya atau tetap membiarkannya dalam naungan wali nasab.

Kewenangan penuh yang tidak ada batasannya seringkali mengakibatkan seseorang berbuat semena-mena terhadap orang lain, apalagi jika orang lain

${ }^{17}$ Lawrence M Friedman , Sistem Hukum Perspektif ...,213. 
tersebut merasa membutuhkan uluran tangannya dan berada di posisi yang lebih rendah. Fenomena itu dapat kita temui dalam penolakan seorang wali nasab untuk bertindak menjadi seeorang wali dalam pernikahan anaknya.

Pada fenomena diatas dikatakan semena-mena karena tidak memiliki landasan hukum yang kuat, baik dari segi agama maupun perundang-undangan yang berlaku di Indonesia. Jika ditinjau dari segi agama orang tua telah melalaikan kewajibannya, hal tersebut sesuai dengan hadits ${ }^{18}$

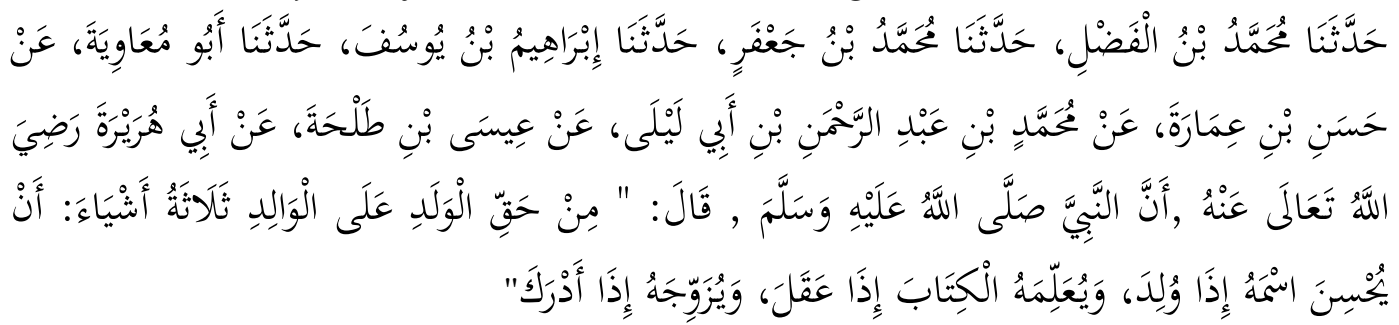

Artinya: Muhammad bin Fadhl bercerita kepada kami, Muhammad bin Ja'far bercerita kepada kami, Ibrahim bin Yusufbercerita kepada kami, Abu Mu'awaiyah bercerita kepada kami dari Hasan bin Imarah dari Muhammad bin Abdurrahman bin Abi Laila dari Isa bin Tholhah, dari Abu Hurairah RA berkata: Bahwa Nabi SAW bersabda: Perkara yang termasuk dari hak anak kepada orang tua ada tiga perkara: Pertama, Mendapatkan nama yang bagus ketika lahir, Kedua. Menagajarkan al-Qur'an ketika sudah berakal, menikahkan ketika telah dewasa.

Paradoksi hukum yang terjadi antara opini publik secara umum dengan perundang-undangan di Indonesia adalah kesenjangan antara legalitas moral dan legalitas prosedural. Jika moral didahulukan maka esensi dari sebuah hukum akan terus jalan ditempat dan calon pengantin akan terus menunggu kepastian akan datangnya restu wali tanpa ada batasan moral meski ada kondisi anak yang memaksa harus bergerak cepat. Semenetara jika legalitas prosedural didahulukan maka pondasi nilaimoral dari bangunan sebuah hukum akan rapuh karena dari awal pembangunan sudah bermasalah. Pada Akhirnya hakim harus berpikir jernih sebelum memutuskan mana yang lebih bermanfaat dan masuk akal dengan tetap memperhatikan unsur kepatuhan dan legitimasi secara umum.

\section{Pengambilalihan Wewenang Wali Nasab Perspektif Struktur Hukum}

Sejarah panjang adanya hukum di Indonesia bermula dari adanya kerajaan-kerajaan kecil yang pernah menguasai nusantara pada abad ke 4 masehi dan hampir bisa dipastikan dalam setiap komunitas masyarakat dalam kehidupan manusia modern terdapat peraturan. Peraturan adakalanya tertulis dan tidak tertulis namun telah disepakati bersama keberlakuannya. Sedangkan hukum islam di indonesia, karena datangnya paling belakang maka islam datang sebagai koreksi atas hukum yang sudah ada. Sebelum islam datang hukum yang

${ }^{18} \mathrm{Abu}$ al-Laits Nashr bin Muhammad bin Ahmad bin Ibrahim al-Samarqandy, Tanbih a lGhofilin (Beirut: Dar Ibn Katsir, 2000), 130. 
sudah berlaku di Indonesia adalah hukum yang berlaku dalam agama hindu dan budha, kemudian berlanjut kepada hukum yang dibawa oleh kaum penjajah yang menganut sistem hukum berlaku menurut agama kristen. Sedangkan Islam di Indonesia berasal dari pembawa risalah kenabian yakni para ulama' yang bermadzhab syafi'iyyah yang di kemudian hari dengan kegigihannya menjadikan Indonesia mayoritas beragama islam dengan hukum islam yang bercorak syafi'iyyah dalam kehidupan masyarakat sehari-hari. Tidak heran kiranya jika hukum di Indonesia, terutama hukum islam juga mengalami kodifikasi di berbagai segmen. Jika Belanda dengan segala atribut agama dan hukumnya datang ke Indonesia pada abad 16, maka jauh sebelum itu pada abad 14 indonesia sudah mengenal lembaga peradilan yang dibentuk walisongo sebelum belanda datang ke Indonesia. Seperti halnya sejarah panjang bangsa indonesia dalam kodifikasi hukum, lembaga peradilan terutama lembaga peradilan agama juga tak luput dari sejarah transformasi dan kodifikasi hukum dari masa ke masa. Jika hukum secara umum dilihat dari periode masa kekuasaan maka hukum di Indonesia terbagi menjadi tiga siklus; pra penjajahan belanda, masa penjajahan belanda, pasca penjajahan belanda hingga sekarang. Dari siklus sejarah peradilan agama dan umum diatas dapat kita tarik benang merah bahwa sebenarnya hukum yang ada di Indonesia yang ada di indonesia adalah kodifikasi dari berbagai hukum.

Kodifikasi hukum di Indonesia secara umum berasal dari perpaduan berbagai sistem, baik itu anglo saxon, civil law, adat, dan agama. Dalam proses kodifikasi sebuah hukum diperlukan pemahaman yang mendalam agar ditemukan ruh atau unsur dari sebuah hukum demi eksistensi keberlanjutan hukum itu sendiri, tanpa adanya unsur sebuah hukum akan berjalan tanpa adanya konsistensi yang akan berujung pada terjadinya hukum yang stagnan, tidak peka terhadap perubahan zaman, dan puncak musibah dari sebuah hukum yang tak memiliki ruh adalah kehilangan legitimasi di masyarakat. Dalam proses kodifikasi sebuah hukum harus memenuhi unsur formil dan materil agar hukum memiliki kewibawaan di mata masyarakat.

Unsur formil dalam sebuah lembaga peradilan agama adalah berupa rangkaian peraturan yang berisi tatacara bagaimana harus bertindak di lembaga peradilan dan bagaimana tindakan lembaga terhadap permasalahan yang ada didalamnya sesuai dengan peraturan yang berlaku. dan itu juga berlaku sama dengan lembaga peradilan umum, ${ }^{19}$ hal tersebut dikecualikan jika terdapat peraturan yang secara khusus menangani peradilan agama seperti yang tertuang dalam Undang-Undang No. 3 tahun 2006 tentang Perubahan atas UU peradilan agama tahun 1989. Sedangkan unsur materilnya adalah segala bentuk hukum islam yang ada di beberapa literatur fiqih klasik dengan segala permasalahan khilafiyyah yang ada didalamnya. Unsur formil dari perkara wali adhal memuat

${ }^{19}$ Basiq Djalil, Peradilan Agama di Indonesia, (Jakarta: Kencana,2006), 147. 
tentang bagaimana proses perkara wali adhal itu harus dijalani oleh seorang pemohon dan bagaimana proses perkara wali adhal itu berjalan di lembaga peradilan agama seperti yang tertuang dalam hukum acara tentang wali adhal. ${ }^{20}$

\section{Pengambilalihan Wewenang Wali Nasab Perspektif Substansi Hukum.}

Fungsi hukum secara substantif menurut Mardani adalah untuk mengumpulkan dan memadukan hukum yang berserakan dan saling bertolak belakang antara hukum satu dengan hukum lainnya agar jika terjadi konflik bisa segera diatasi, ${ }^{21}$ hukum yang substantif itu meliputi undang-undang, living law, dan hukum yang terlegitimasi. Legitimasi bisa dianggap sebagai pandangan umum masyarakat tentang suatu fenomena hukum.

Hakim sebagai subyek hukum dalam melahirkan sebuah putusan harus berjiwakan pancasila sebagai substansi dari segala hukum yang ada di Indonesia, termasuk dalam perkara wali adhal. adapun sila yang paling cocok dengan perkara wali adhal adalah sila kelima pancasila; keadilan sosial bagi seluruh rakyat indonesia.

Pada perkara wali adhal ketidak adilan terjadi karena kedua belah samasama memiliki hak, akan tetapi pada faktanya terutama di masyarakat secara umum anak dianggap sebagai pihak yang tidak memiliki hak untuk menentukan pilihan pasangan hidup dan jalan kehidupannya sendiri, padahal semua orang memiliki hak dan kewajiban yang berimbang. Posisi hakim dengan kekuasaannya ketika terjadi konflik adalah ditengah diantara dua kubu yang berkonflik, meski didalam perkara wali adhal pandangan masyarakat mayoritas adalah mendahulukan etika daripada menegakkan hukum.

Seorang hakim menurut Suhrawardi memiliki tanggung jawab secara moral yang harus bisa dipertaruhkan, hal itu disebabkan oleh adanya pengaruh efek dari putusan tersebut di lain kesempatan, selain di masa putusan tersebut keluar sampai kepada orang lain untuk kemudian menjadi dokumen salinan di pengadilan sebagai pertimbangan hakim dalam memutuskan perkara yang sama di momen-momen selanjutnya; selain kondisi terkini yang membutuhkan kajian mendalam dari hakim juga kondisi yang akan datang sebagai pijakan hukum yang mantap dikemudian hari. ${ }^{22}$

Definisi substansi hukum dalam putusan perkara wali adhal itu sudah sesuai dengan pembukaan UUD 1945 yang salah satunya berasaskan keadilan karena dilandasi oleh persamaan warga negara untuk mendapatkan hak dasar yang telah diakui dan dilindungi oleh undang-undang. Dalam permasalahan wali adhal seorang anak memiliki hak dasar untuk membangun keluarga sendiri yang sah secara hukum sesuai dengan peraturan dan perundang-undangan yang

23.

${ }^{20}$ Mardani. Pengantar Ilmu Hukum Islam di Indonesia, (Yogyakarta: Pustaka Pelajar, 1981),

${ }^{21}$ Mardani, Pengantar Ilmu Hukum Islam di Indonesia, 20.

22Suhrawardi K Lubis, Etika Profesi Hakim ( Jakarta: Sinar Grafika, 2002), 29. 
ada di Indonesia, selain berkeadilan yang menjadi inti dari substansi hukum; perkara wali adhal juga sesuai dengan asas kebermanfaan dan asas hukum yang darurat dari keluarnya putusan hakim. Dikatakan darurat karena putusan hakim itu adalah satu-satunya jalan agar anak segera terhindar dari bahaya zina ditengah kebuntuan karena anak tidak menemukan jalan untuk mendapatkan persetujuan dari wali nasab. Pandangan hakim dalam putusan wali adhal tidak jauh berbeda dengan opini sebagian masyarakat yang berwawasan terbuka dan mempunyai peranan secara langsung terhadap perkara wali adhal yang pada akhirnya diakui juga oleh tokoh-tokoh pemuda masyarakat. Harapan dari adanya putusan hakim tersebut disamping sebagai dokumen pribadi lembaga peradilan juga sebagai pintu pembuka kesadaran masyarakat secara luas menuju hukum yang adil, memiliki manfaat secara merata, tanpa adanya diskriminasi, dan menjunjung tinggi persamaan derajat manusia dalam kehidupan sosial masyarakat madani sesuai dengan amanat undang-undang.

\section{Pengambilalihan Wewenang Wali nasab Dalam perkara wali adhal perspektif pembangunan hukum.}

Berangkat dari fenomena yang terjadi dalam proses keluarnya putusan wali adhal yang bermula dari masuknya permohonan dari pihak yang berperkara sampai pada tahapan terakhir pindahnya kewenangan wali nasab kepada pejabat KUA dengan berdasarkan keluarnya sebuah putusan hakim pengadilan jika kita amati dari teori pluralisme hukum akan tampak ada yang tertinggal dari bangunan teori yang telah disusun oeh Friedman.

Jika Friedmaan dalam teorinya hanya menjelaskan tentang pemetaan hukum dari segi aspek kultur,struktur, dan substansinya maka Muhtar Kusumaatmaja melalui teori pembangunan hukum menekankan kepada masyarakat dan pemangku kebijakan akan pentingnya sebuah proses yang harus dijalani oleh semua pihak baik itu dalam masa sebelum adanya putusan sampai pada harapan yang akan muncul dari sebuah putusan.

Hukum menurut Muhtar kurang lebih sama dengan Friedman demi ketertiban masyarakat yang menjadi substansi dari sebuah hukum. Akan tetapi lebih jauh Muhtar menambahkan friedman meskipun berasal dari pemikiran roscoe pound bahwa hukum itu berfungsi sebagai alat untuk merubah kondisi sosial masyarakat (law is tool of social enginering) muhtar juga menambahkan pemikiran roscoe pound dengan adanya hukum itu harus berfungsi sebagai alat ketertiban dalam membangun sebuah hukum, dan yang terpenting dari kesemuanya adalah terjaganaya nilai sosial dari terbentuknya sebuah hukum ${ }^{23}$.

Muhtar menekankan pentingnya penjagaan nilai yang harus tetap ada dalam setiap pembaharuan hukum, karena negara indonesia semenjak dahulu

${ }^{23}$ Muhtar Kusumaatmaja, Konsep-Konsep Hukum dalam Pembangunan (Bandung: PT. Alumni, 2013), 10. 
kala sebelum mengenal peradaban sudah berbeda dengan negara manapun. Jika nilai substansi hukum yang telah disepakati oleh para ahli hukum itu adalah keadilan maka menurut Muhtar bukan hanya keadilan, akan tetapi juga harus ada proses dan nilai moral dari kearifan lokal sebuah komunitas yang juga tetap harus dilestarikan.

Jika dihubungkan dengan peraturan tentang wali adhal, tanpa adanya unsur proses yang harus ditempuh oleh seorang anak sebagai pihak pemohon, maka perkara wali adhal adalah hukum yang statis yang hanya berupa kajian hukum normatif seperti halnya dokumen yang tak memiliki nyawa.

Lebih jauh Muhtar menekankan pentingnya penjagaan nilai moral dari seorang anak kepada seorang wali nasab sebagai kritik atas posisi wali nasab di pengadilan yang tidak bisa membatalkan sebuah putusan pengadilan tentang perkara wali adhal meskipun secara nasab wali adalah orang terdekat yang berhak menjadi wali nikah, yang bisa dilakukan hanyalah menggalang opini di tengah masyarakat dengan harapan permasalahan yang menimpa keluarganya tidak menyebar kepada keluarga lainnya.

Hakim sebelum mengeluarkan putusan wali adhal harus terlebih dahulu mengadakan mediasi, jika hal itu tidak dimungkinkan hakim sebagai pemegang tongkat panglima hukum berhak memanggil tokoh masyarakat yang disegani agar pertikaian yang terjadi antara anak dan wali nasab dalam perkara wali adhal bisa segera diakhiri.

\section{Kesimpulan}

Pertimbangan hakim dalam putusan wali adhal adalah demi maslahat mendesak dan darurat agar terhindar dari zina. Disamping itu hakim juga melindungi hak dasar masyarakat sesuai konstitusi untuk mempertahankan hidup dan melanjutkan keturunan yang sesuai dengan pasal 28 serta demi keadilan sosial bagi calon pengantin karena haknya terhambat oleh orang lain, pandangan hakim tersebut diikuti oleh tokoh masyarakat yang berperan langsung dalam permasalahan pernikahan. Pertimbangan hakim tersebut bertolak belakang dengan tokoh masyarakat yang tidak berperan langsung dalam pernikahan, mereka beranggapan bahwa menjaga tradisi itu lebih penting daripada menegakkan hukum, karena jika tradisi diabaikan maka akan ada dampak negatif yang akan muncul.

Jika pengambilalihan wewenang perwalian oleh hakim dalam perkara wali adhal ditinjau dengan teori pluralisme hukum maka akan muncul tiga segmen: Pertama, Struktur Hukum. Kedua, Kultur Hukum. Ketiga, Substansi Hukum. Struktur hukum adalah hukum yang berlaku di lembaga struktural pengadilan dengan peraturan tertulis dalam satu wilayah politik hukum yang mengatur tentang wali adhal dan pengambilalihan wewenang dari wali nasab ke wali hakim yang ada di dalamnya. Kultur hukum adalah hukum yang sudah menjadi tradisi masyarakat bahwa jika keinginan untuk menikah tidak disetujui wali nasab maka hendaknya keinginan menikah dibatalkan, karena akan ada 
efek samping berupa sanksi sosial dari masyarakat karena dianggap durhaka dan mengabaikan nilai sosial kepada wali nasab. Substansi hukum meliputi inti permasalahan yang menjadi perdebatan adalah terjadinya pernikahan. Demi menghindari zina dan demi keadilan calon pengantin yang haknya terhalang wali nasab maka hakim berhak memberikan rekmendasi kepada calon pengantin untuk melanjutkan kehendaknya melangsungkan pernikahan.

\section{Daftar Pustaka}

\section{Al-Qur'an Al-Karim}

Abu al-Laits Nashr bin Muhammad bin Ahmad bin Ibrahim al-Samarqandy, Tanbih al-Ghofilin, Beirut: Dar Ibn Katsir, 2000.

Ahmad bin Hambal, Al-Musnad, Kairo: Dar al-Hadits,1995.

Al-Bukhori, Muhmammad bin Ismail, Al-Adab Al-Mufrod, Riyadh: Al Ma'arif,1998.

Al-Jazairi, Abdul Rahman. Al-Figh Ala Madzahib Al-Arba'ah, Beirut: Dar al-Fikr,tt. Al-Jurjani, Ali Ahmad, Hikmah al-Tasyri' wa Falsafatuhu, Beirut: Dar al-Fikri,1974. Al-Qozwiny, Muhammad bin Yazid, Sunan Ibn Majah,, Beirut: Dar al-Fikri,1995. Al-Qurthuby, Abu Abdillah ,Al-Jami' li Ahkami al-Qur'an, Beirut: Dar al-Fikr, tt. Al-Syathibi, Abu Ishaq. Al-Muwafaqat, Beirut: Dar al-Fikri, 2010. Al-Saqqaf, Alwi. Fath Al-Mu'in, Beirut: Dar al-Fikr,tt .

Djalil Basiq, Peradilan Agama di Indonesia, Jakarta: Kencana,2006.

Friedman, Lawrence M. Sistem Hukum Perspektif Ilmu Sosial. Bandung: Nusamedia, 2017

Husaini Usman dan Purnomo Setiadi, Metodologi Penelitian Sosial, Jakarta: PT. Bumi Aksara, 2004.

Kelsen, Hans, Teori Hukum Murni, Dasar-Dasar Ilmu Hukum Normatif, Bandung: Nusamedia, 2016.

Kompilasi Hukum Islam, Jakarta: Wacana Intelektual, 2009.

K Lubis Suhrawardi, Etika Profesi Hakim, Jakarta: Sinar Grafika, 2002.

Mardani. Pengantar Ilmu Hukum Islam di Indonesia, Yogyakarta: Pustaka Pelajar, 1981.

Muhammad Idrus, Metode Penelitian Ilmu Sosial, Jakarta: Penerbit Erlangga, 2009.

Muhtar Kusumaatmaja, Konsep-Konsep Hukum dalam Pembangunan, Bandung: PT. Alumni, 2013.

Ramulyo, Idris, Hukum Perkawinan, Kewarisan dan Hukum Acara Pengadilan Agama dan Zakat, Jakarta: Sinar Grafika, 2006.

Sastroatmodjo, Arso dan Aulawi, Wasit, Hukum Pernikahan di Indonesia, Jakarta: Bulan Bintang, 1975.

Sugiyono, Metodoligi Penelitian Kuantitatif Kualitatif dan RED. Bandung: Alfabeta, 2008.

Zahroh, Abu, Figh al-Islam, Cairo: Dar al-Manar, 1990. 